\title{
Synne Skjulstad
}

\section{Vetements, mémek és konnektivitás: Divatmédia az Instagram korában}

\begin{abstract}
Absztrakt
E tanulmány a Vetements körüli, sokat vitatott tervezői közösséget az internetes kultúrához és a digitális konnektív mediációs gyakorlatokban való kortárs részvételhez kapcsolja. A Vetements tervezôi tevékenysége stratégiailag hangsúlyos központi elemévé tette a kortárs internetes kultúra lényegi összetevôit. Tervezôi és kommunikációs gyakorlatait az internetes mém logikája hatja át, miközben erôteljesen épít a részvételi kultúrára és a konnektivitásra. A Vetements a múvészet (és a posztmúvészet) területének irányzataiba tagozódik be, reflektál azokra, belólük és nem ellenükben építkezik. Ahhoz, hogy megértsük, e tervezôi csoport hogyan válik a divatközvetítés változó esztétikájának részévé, kommunikációs tevékenységüket az internetes kultúrára és fôként az internetes mémekre vonatkozó jelenkori kutatások perspektívájában kell vizsgálnunk. A Vetements önpozicionálása a vizuális digitális média ökonómiájában a kisajátítás és ready-made jelenségein keresztül a divatmém terminusa által írható le.

\section{Szerzó}

Synne Skjulstad a norvégiai Kristiania University College kommunikáció és design tanszékének oktatója. A dizájnelmélet, a divattervezés, az esztétika és a közösségi média közötti érintkezési pontoknak szentelt elemzései olyan fontos folyóiratokban jelentek meg, mint a Fashion Theory, The Journal of Media Innovations. Vezetô kutatója volt a Norwegian Fashion: Cultural Production and Aesthetic Media Practice címú projektnek.
\end{abstract}

https://doi.org/10.31176/apertura.2019.15.4.1 


\section{Synne Skjulstad}

\section{Vetements, mémek és konnektivitás: Divatmédia az Instagram korában}

\section{Bevezetés}

E tanulmány a digitális és hálózati divatnak a Vetements márka által képviselt megnyilvánulásait vizsgálja különös tekintettel arra, hogy mindez hogyan jelenik meg az Instagramon. Miközben azt tárgyalja, hogyan változnak a divatmárkázási gyakorlatok, illetve hogyan tervezik e folyamatokat egyre inkább a médiaértôk, a digitális divat követôi és fogyasztói ízléskultúrájának kiszolgálására, e tanulmány azon módozatokat vizsgálja, melyek által a Vetements körüli divattervezői közösség becsatlakozik a kortárs internetes kultúrákba, s így az internetes mémek kulturális logikája nemcsak a digitális közvetítés folyamataiba, hanem a ruházat anyagiságába és a termékekbe is beépül. Továbbá azt vizsgálja, hogy adott ízlés-közösségek hálózati médiagyakorlatai hogyan alapozzák meg a Vetements divatközvetítését a közösségi médiában.

A Vetements egy olyan tervezôi csoport, mely a Keleti Blokk örökségét és a jól beágyazott divatházak tapasztalatát viszi tovább, és e tapasztalatokat a kortárs digitális médiakultúrák alapos megértésével kombinálja. A mediatizált divatmárkázás kontextusában ez a kombináció mind gazdasági, mind esztétikai szempontból értékes valuta. Az általam megválaszolni próbált kulcskérdés a következô: Hogyan épitette be a Vetements mediációs és tervezôi gyakorlataiba a kortárs internetes kultúrát? Hogyan lehet az internetes mém a kortárs divatterjesztés és tervezés megértésének heurisztikus modellje?

A Vetements 2017-es tavaszi/nyári és ôszi/téli kollekcióinak forgalmazásából és darabjaiból kiindulva a tanulmány azt tárgyalja, hogyan épül be a divat és annak terjesztése egyre inkább abba, amit van Dijk a konnektivitás korszakának nevez (van Dijk 2010). A Vetements pariódiamárkát vizsgálva amellett érvelek, hogy a mémekre vonatkozó tudományos vitát (Davidson 2012, Shifman - Nissenbaum 2014, Shifman 2014), illetve a konnektivitásnak a kortárs internetes kultúra és közösségimédia-logika keretében történô megértését (van Dijk - Poell 2013, Joselit 2013) a divattal kombinálva betekintést nyerhetünk a kortárs divatmediációk és azok dinamikájának megértésébe.

Az elemzést, egyfajta vizuális retorikai gépezetként, kiegészíti egy fotósorozat, mely metaforikusan megismétli e tanulmány fő állításait. E fotók megjelenítik a Vetements design mémszerú esztétikájának gyakorlati vizsgálatát, és egy kiegészítô vizuális réteget adnak hozzá a tanulmány értekezô egységéhez. E fotókat a módszertani alfejezetben tárgyalom részletesebben. 
Az internetes mém analitikus fogalmának a Vetements kontextusában való tárgyalása és transzponálása által elemzésem célja az, hogy tovább gyarapítsa a média- és kommunikációtudományok, illetve a divattudományok közötti sokféle, gyümölcsözô és már létező érintkezést.

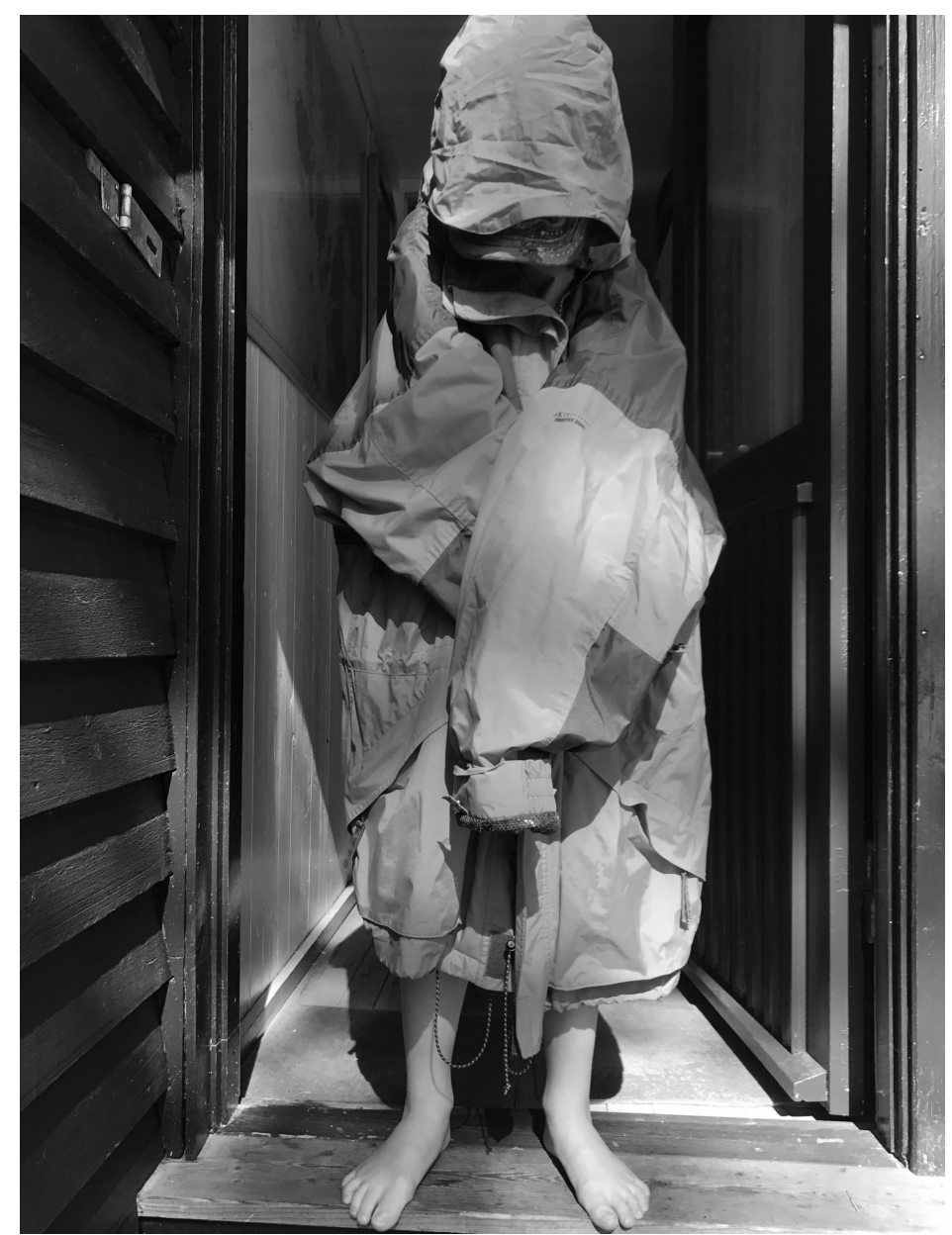

A kapucni, a túlméretezett kabát, a hosszú ujjak és sok gardrób alapdarabjait képezö ruhadarabok széles, átdolgozott,

luxuskivitelezésü változatai a Vetements divatértelmezésének központi elemei. A képen egy vintage esókabát és egy Panduro Hobby díszített sapka látható. Modell: Otto Skjulstad. Fotó: Synne Skjulstad.

Minthogy a divatipar sosem pihen, a Vetements-ról írni olyan képtelen vállalkozás, mintha egy fapapucsot viselố gepárdot akarnánk elkapni. E ténnyel számolva, tanulmányom a következők szerint épül fel. Elôbb a divatmédia fogalmát tárgyalom, majd a módszerek rövid ismertetése következik. Ezt követi a kutatás elméleti pozicionálásának tárgyalása, majd a Vetements divatközvetítési gyakorlatait illusztráló kiválasztott esetek bemutatása. Ezek a Dry Cleaner pop-up eseményre, az összefirkált Instapump Fury sportcipókre, illetve a DHL logisztikai cég vizuális arculatának a márka dizájnjába és kommunikációjába való beépítésére fókuszálnak. A tanulmány következtetése a divatmém fogalma felól értelmezi a Vetements-nak a kortárs közösségi média 
logikájába illeszkedô gyakorlatait, s ezáltal jut el annak árnyaltabb megértéséhez, ahogyan a divat elsajátítja és kisajátítja a közösségi média logikájának irányzatait.

\section{Divatmédia}

A divatot a formák és formátumok kiterjedt ökológiájában sûrûn átszövi a digitális fordulatra reflektáló nyomtatott és hálózati médiagyakorlatok széles spektruma (Rocamora 2016, Skjulstad 2017a, Skjulstad - Morrison 2017). Jelen pillanatban a divat kommunikációja komoly változásoknak van kitéve, hiszen az iparág átveszi és magáévá teszi ezt a mediális áramlást (Arnold 2009). A divatközvetítés a már kiépült formátumoktól az új digitális médiumkeresztezô, többplatformú múfajok felé mozdul el (ld. Uhrilova 2013, Skjulstad and Morrison 2016), a kreatív múvészeti felfedezés elôtt nyitva meg az utat (Skjulstad 2017a, 2017b). Mindez a van Dijck és Poell által leírt újmédia-logika része, mely az újmediális kommunikáció „dinamikáját múködtetô normákra, stratégiákra, mechanizmusokra és gazdasági folyamatokra” (2013: 1) vonatkozik. Miközben a média- és kommunikációtudomány, illetve a divatelmélet elméleti perspektíváját a posztmúvészetre ${ }^{[1]}$ vonatkozó tudományos munkákkal kombinálja, e tanulmány a divat mediális közvetítésére fókuszál, arra, amit divatmédiának nevezhetünk.

A divatmédia fogalmát nehéz teljességgel kifejteni, hiszen a divat is ellentmondásos fogalom, melynek jelentése a testhasználatoktól, az anyagi tervekig, a stílusokig és a megszépítésig, a hétköznapi gyakorlatok új módozataiig terjed (Entwisle 2011, Skjulstad 2017). A médiát mint fogalmat sem kevésbé könnyú meghatározni. Hansen és Mitchell (2010: xiii) McLuhan és Stiegler alapján használják a fogalmat, miszerint a plurális média „a humanizálás ontológiai feltétele - az exteriorizálás és invenció lényegi múvelete”. Ugyanakkor e tanulmány középponti fókusza nem önmagukra a médiatechnológiákra irányul, hanem arra, hogy a különböző médiatechnológiák, platformok és formátumok ökológiájának jelentôsége „az általuk közvetített információhoz képest nem természetes vagy transzparens, alárendelt vagy tisztán másodlagos”, ahogyan azt Hansen és Mitchell (2010: vii) állítják. 
Mindez ugyanakkor a mediális márkázás és a reklám változó természetérôl (Arvidson 2006, Duffy\&Hund 2015) is szól, ahol a közönséget az esztétikai alkotás folyamataiba való belépésre sarkallják, a felhasználóbarát esztétikában partnerré teszik úgy, hogy mindeközben a Vetements dizájn paraméterei és formai keretei nem változnak. Ami a divat demokratizálódásának tûnhet - a részvételi fordulat -, a játékos társtervezôi tevékenységnek álcázott promóciós diskurzus új móduszaként kritizálható. Itt amellett érvelek, hogy a kortárs divatkommunikáció és márkázás legfontosabb összetevôje az, hogy létrehozza azokat a technikai-esztétikai feltételeket, melyek a fogyasztói divatgyakorlatokat lehetôvé teszik, s melyek az Instagram és más hasonló programok hálózatában közvetítődnek. Mindezek vizuális streamek (ld. Skjulstad 2017) vagy David Joselit(2013) által képpopulációknak, buzzoknak nevezett elemként tûnnek elénk.

\section{Módszerek és esetválasztás}

Elemzésem vegyes módszerrel, kvalitatív és szöveges vizsgálattal közelít a hálózati, mediált divat (Jenss 2016) kérdésköréhez, ugyanakkor fényképekkel dokumentálja és támasztja alá vizuális és gyakorlatorientált érveit. A következôkben a Karlsen (2017) által meghatározott online etnográfiára is támaszkodom, hiszen több mint egy évig napi rendszerességgel figyeltem meg nagyjából négyszáz divatszerkesztô, divatfotós, stylist, márka és influencer Instagramon folytatott online párbeszédét, és részt is vettem benne. Karlsen az online videojáték-folyamatokra alkalmazza fogalmát, így az övétől különböző és visszafogottabb diszkurzív részvételi megközelítés kidolgozása kulcsfontosságú volt. E gyakorlat képek lájkolását, saját képeim posztolását, illetve releváns Instagram-felhasználók követését feltételezte, idônként különböző témák kommentálását és tárgyalását is. A márka Instagram-megjelenéséhez kapcsolódóan olyan képernyô-tartalmakat és vizuális megjegyzéseket választottam ki és tanulmányoztam, melyek széles skáláját tárták fel azon társult és partnermárkáknak és intézményeknek, amelyekkel a Vetements mediális, stratégiai és kreatív okok miatt együttmúködött. Ugyanakkor a kulcsszerepet játszó képek kiválasztása annak alapján történt, amit Cubitt (2013) anekdotikus bizonyítéknak nevez, s ahol a fó hangsúly az egyediségtôl és a partikuláristól az átfogóbb jelenség felfedezése felé tartó úton van.A szövegelemzéssel és értelmezô módszerrel feldolgozott példák az esettanulmányhoz kapcsolódnak, a mediált divat egyedi példái, és nem merítik ki más lehetséges mediációk skáláját. Ugyanakkor a tanulmányban megfogalmazott érvek vizuális magyarázataként egy 2017-ben készült fotósorozatot is beiktattam. Ezek a fotók a vizuális retorika eszközeiként szolgálnak, és abból a célból készültek, hogy a kutatást a partikuláris esethez kapcsolják; a konkrét példáktól a divat mediális artikulációi felé haladva vizuális eszközként szolgálnak a Vetements által alkalmazott mém típusú esztétikai gyakorlatra. A hivatkozott divatfotók célja, hogy megmutassák, milyen lenne a Vetements-esztétika utánzása akkor, ha alkotásaik közül egyet sem használnánk fel. A ruhák és a csizmák a szerzô szüleinek a nyaralójából származnak. A csizmákat több mint húsz évvel korábban „Manolo Blahniknak” nevezte el az anyám, viccesen utalva divat iránti érdeklődésemre, amikor fiatal nôként egy esôs napon nem akartam felvenni ôket. A csizmát 
késôbb, több mint húsz évre rá, a szerzó és fia díszítette ki. A fiú modellként is feltúnik az egyik képen. A fotókon használt ruhadarabokat a hétvégi házban ôrizték a nyolcvanas-kilencvenes évek óta pótgardrób elemeiként. A kiválasztott darabok és tárgyak, mint az esókabát és az öngyújtó, a Vetements vizuális szótárának kiemelkedô elemei, ugyanakkor hétköznapi környezetben könnyúszerrel elérhetôek. A hétvégi ház a divathoz vagy a Vetements vizuális stílusához semmiben sem kapcsolódott, vagy legalábbis nem magától értetôdô elemekkel kapcsolódó kontextust teremtett. A fotózott és átalakított ruhadarabok már a kezdetektôl fogva ott voltak ugyanúgy, ahogy a Vetements által újradizájnolt vagy kifordított eredeti darabok is. A hétköznapi ruhadarabok és tárgyak kisajátításának kutatása közben az öltözékek vizuális szótárát játékosan teremtettük újra és hoztuk ismét játékba, egy nagyon nem divatos nyári lak ruhatárának szúkös keretei között tettünk vizuális felfedezőutat.

Az olvasót arra biztatom, hogy nyissa meg a Vetements Instagram-oldalát, és nézze meg közelebbrôl (@vetements_official). Mivel ez a felhasználói fiók több mint 3500 posztot tett közzé a cikk megírásának pillanatáig (2018), ezek a képek e felületen a márkának erôs jelenlétét biztosítanak. E fotók mindazon résztvevốk tartalmaira rezonálnak, akik a közösségi média eltérô platformjain, múfajaiban és kontextusaiban megosztják, kiforgatják vagy elsajátítják a Vetements vizuális stílusát.

\section{Fogalmak/elméleti keretezés}

A divattudományon belül a divatközvetítésben a média és a média változó szerepére összpontosító kutatások nagyon sokfélék. A számos médiaökológiai felfogás és a divatot a mozgásban levô mediális összkép részeként elképzelô vizsgálatok közötti átjárás már annyira elmosódott, hogy a divattudósok, a média és a divat együttes fejlôdésének jobb megértésére törekedve, elméleti megközelítések és koncepciók után kutatva, egyre inkább a média- és kommunikációtudományok felé tekintenek. Hasonlóképpen a média és a kommunikáció kutatói számára a divat érdekes kutatási terület a kortárs médiagyakorlatok és fejlemények tanulmányozására, hiszen e területet a finoman összehangolt jelek és a szemiotikai megkülönböztetések jellemzik. A digitálisan közvetített divatfilmformátumot például történeti kontextusban tárgyalta úttörô cikkében a filmés divatkutató Marketa Uhlirova (2013), majd ezt a feltörekvô múfajt ökológiai perspektívában és a múfaji innováció példájaként elemezte Skjulstad és Morrison (2016). A divattudomány és a médiaés kommunikációtudomány közötti érintkezés megteremtését elôsegítendô Rocamora (2016) a divatközvetítés jelentôségének kereteként a mediatizáció fogalmát dolgozza ki. A szociológiai alapú médiatudományból származó fogalom, a mediatizáció folyamatainak tudományos vizsgálata (Lundby 2009) a médiára úgy tekint, mint - ahogyan Rocamora fogalmaz - ami központi jelentôségúvé vált „az egyének és intézmények formálódása és cselekvése, tapasztalataik és gyakorlataik" szempontjából. Ugyanakkor a mediatizációra fókuszáló kutatások a globális perspektíváról szólnak, és nem foglalkoznak olyan konkrét esettanulmányokkal, mint a divat és 
film, a divatfotó vagy az Instagram-feedek szöveges elemzése. Rocamora (2016) azon kevés kutató egyike, akik összekapcsolják e makroszintû vizsgálatokat a divat konkrét mediációinak kérdésével. A mediatizáció fogalmára vonatkozó kutatások széles spektrumára támaszkodva összekapcsolja egymással a makroszint vizsgálatát és a divat sajátos mediális színre vitelét. Arról értekezve, hogy a mediatizáció folyamatai hogyan hatnak a divatközvetítésre, olyan mélyelemzésekkel szolgál, melyek a divatbemutatók kommunikációjának és dizájnjának, a divatkereskedelemnek és a sminknek a szerepét értelmezik ezekben a folyamatokban. E fejlemények tükrében, és a digitális fordulat keretében a médiának a divatban való megnövekedett szerepére irányuló fokozott figyelem részeként, a divattudomány nagy érdeklődéssel fordul a divatközvetítés új formái, formátumai és platformjai felé, mint az online divatfilm (Uhlirova 2013, Muriale 2014, Khan 2012a és b, Skjulstad\&Morrison 2016), a divatközvetítés olyan digitális platformokon, mint az Instagram (Skjulstad 2017, Rocamora 2016) és a divatblogok (de Perthuis 2015, Lewis 2014). A divattudomány egyre inkább tárgyalni kezdi a digitális média kommunikáció- és médiatudományi kérdéseit, melyeket kezdetben „újmédiaként” írtak le (Skjulstad 2017a). Példának okáért a divatkutatók felhasználták Lev Manovich állandó jelenlét (Rocamora 2013, Kahn 2012), Jay David Bolter és Richard Gursin remediáció fogalmait (Bolter\&Gursin 1999) és George Landow hipertextrôl szóló fontos könyvét (Rocamora 2013). Ezeket a munkákat a kortárs divatmédiát érintô tudományos kutatások átértékelték. Bár ezek a digitális médiáról szóló fontos írások a digitális hálózati média és a médiatechnológiák érintkezését kielégítôen tárgyalják, más, újszerúbb nézôpontok a digitális médiakultúra és az internetkultúra alakulásáról, gyümölcsözố megközelítést biztosíthatnak annak megértésére, ahogyan a divat egyre inkább részévé válik az új múfajok és a digitális megjelenítés zavaros ökológiájának. Mark Deuze (2007, 2010, 2016) média-, újságírás- és reklámkutató munkáira támaszkodva a média úgy konceptualizálható, mint életünk infrastruktúrája, mely lehetôvé teszi a mindennapi élet és a társadalmi tapasztalatok feltételeit, s nem pedig valami külsődleges, idônként igénybe vett entitásként. Deuze médiafogalma, mint mindenütt jelenlevô társadalmi-kulturális életkeret, további vizsgálatokra sarkall a populáris internetes kultúra és a médiaközvetítés témakörében, melyek figyelembe veszik a kialakulóban levô internetalapú populáris kultúra újdonságait úgy, ahogyan azok az online és az Instagramhoz hasonló mobil platformokon megtörténnek. Különösen a sokféle területhez - például a digitális média és vizuális kultúra területéhez (Shifman 2014, Nissenbaum\&Shifman 2017, Milner 2013) kapcsolódó kutató által tárgyalt - internetes mém fogalma nyújt betekintést az internetes kultúrára jellemzô részvételi gyakorlatok területére, amit Henry Jenkins (2006) konvergenciakultúrának nevezett. Jelen tanulmány kiemeli Shifman fotóalapú internetes mémekre vonatkozó kutatásaiból a prospektív fotográfia és az operatív jel fogalmát (2014: 341), és beépíti ezeket a divatmém fogalmába. Míg a prospektív fotográfia olyan fényképekre vonatkozik, melyeket „eljövendő újrahasznosításaik nyersanyagaként fognak fel”, az operatív jel pedig olyan „szöveges kategóriákra, melyek kreatív alkotásra hívnak", a divatmédia mikroirányzatainak mémtípusú jellemzôi a Vetements alkotói és közvetítési stratégiáinak mélyelemzése során kerülnek tárgyalásra. Ezek a stratégiák részvételi cselekvésre, kifordításra, DIY-gyakorlatokra, ellenállásra és vitára sarkallják a 
fogyasztókat a márka témakijelölő (agenda-setting) szándékának meggyôzoó technikáiként, s ezzel a közbeszéd középpontjába kerülnek. Ezek a fogalmak alapozzák meg a divatmém kifejezést. A divatmém olyan divatra utal, melynek mediációja és tervezési gyakorlatai a jövőre irányulnak és kollaboratívak. A divatmém tehát olyan termék vagy ruhadarab, melyet a mémhez hasonlóan másolásra, módosításra, változtatásra, megosztásra, terjesztésre és kommentelésre terveztek. Mindez éles ellentétben áll az eredetiként elképzelt dizájnnal, a dizájnnal, mellyel nem ajánlott vitába szállni, s amely a másolás és imitáció ellen száll síkra. A Vetements tudja, hogyan tökéletesítse a divatmémet, mely akaratlagosan mossa össze az eredeti és a kópia közötti határt, és amelyet a jövőbeli másolatok és ismétlések sablonjaként hoztak létre, divatként, mely azért van, hogy jövôbeli cselekedetek és átírások kiindulópontja legyen.

\section{„Virális esztétikák”?}

A Vetements posztszovjet esztétikája már régóta virálissá vált. A 2017-es februári párizsi divathéten bemutatott tavaszi/nyári kollekció azzal hívta fel magára a figyelmet, ahogyan a bemutató modelljeit stilizálták és választották ki. A kollekció Ari Versluis és Ellie Uyttenbroek fényképes múvészeti projektjének, az Exactitudes-nek a megidézésével a különbségek, hasonlóságok és sztereotípiák problémáját járta körül. A Vetements egy olyan korszakban irányította magára a divatipar figyelmét, amikor a megosztott mémek készletéhez való tartozás többet ér, mint a közös génkészlethez való tartozás. Ennek a megállapításnak középponti jelentôsége van a Vetements iparágon belüli megosztó kultuszának megértésében.

Instagram-feedjük tartalmait pörgetve sápadt, csuklyás, fiatal emberek street-fotóit látva szemétládák és sarki kisboltok elôtt, rájövünk arra, hogy mindez a kortárs divatkommunikáció fordulatára utal, ahol az „autentikusnak” túnő keresése, mely önmagában nagyon problémás fogalom a divatban, sokkal glamúrosabb, mint egy Karib-tengeri naplemente. Ahogyan a divatfotózás kutatójának, Charlotte Andersennek (2006) a divatfotó történetérôl szóló átfogó vizsgálata kimutatta, a divatfotó instabil médium, melyben az esztétikai transzgressziók a folyamatosan mozgásban levô múfaj részei.

\section{Vetements}

A Vetements (francia szó, jelentése 'ruhák') alkotói közösségként múködik, amelyben a grúziai kreatív igazgató, Demna Gvasalia a leginkább önálló arculattal rendelkezó tervezô. Testvére, Guram Gvasalia a CEO. A közösség középponti szereplôje a szintén erôs arculattal rendelkezô stylist, Lotta Volkova, aki maga is befolyásos figura a divatiparban, és gyakran túnik fel modellként a bemutatókon. A dizájner csapat többi tagja kevésbé mediatizált szereplôk, de mindannyian sok szálon kötôdnek az orosz divat- és kulturális szcénához.

Elsố kollekciójuk 2014-es bemutatója után a márka a mellôzött szerepból iparági témakijelölố 
ágenssé lépett elő. Mindezt váratlan fordulatok, humor, irónia, ellentmondásos

antikonceptualizmus egyedi vegyítése által érték el, s e tényezôk mind a kollekciókat, mind a márka nyilvános arculatát áthatják. Ezen tendenciák a stylingra, a modellekre és azok kiválasztására egyaránt vonatkoznak, zenészeket, múvészeket és az utca emberét egyaránt kifutóra viszik. A Vetements kijelentette, hogy egy ideig nem fognak divatbemutatókat szervezni, s ezt követôen a teljes 2018-as tavaszi-nyári kollekciót az Instagramon és Zürichben látható nyomtatott plakátokon mutatták be, közremúködôiket és a város polgárait kérték fel street style modelleknek, majd kicsivel késôbb visszatértek a kifutó formátumához.

Antwerpeni háttérrel és radikális szemlélettel (ahol Gvasalia tanult, majd dolgozott a Martin Margielának), illetve a nagymárkáknál (Marc Jacobs és Louis Vuitton) szerzett tapasztalattal, Gvasalia ma a Balenciaga márkának is a kreatív igazgatója. Mialatt számos divatház nagy konszernekhez tartozik (LVMH és Kering), a Vetements önálló, egyfajta indie-divatmárka. Ily módon biztosítják kreatív szabadságukat, s nem kell egy többnemzetiségú világszervezet elvárásaihoz alkalmazkodniuk, mialatt a Balenciaga révén a Keringben messzemenóen benne vannak.

A Vetements egy olyan egyedülálló stílusú univerzumot teremtố kulcsszereplôvé vált, ahol a posztszovjet vizuális kultúra nosztalgikus átesztétizálása világosan elhatárolódik a magaskultúrához kapcsolódó jelrendszer glamúros reprezentációitól, melynek történetileg számos nagy divatmárka kommunikációjában meghatározó szerepe volt. Mialatt folyamatosan korlátozzák a termékeikhez való hozzáférést, a piac jól ismert mechanizmusával mesterien játszanak. A termékek korlátozott számú kínálata világos logikát követ: amikor a kereslet meghaladja a kínálatot, akkor exkluzivitás és vágyakozás az eredmény. A Vetements emellett a stratégia mellett teszi le a voksát, amikor elkerüli azt, hogy a felesleges termékek felgyülemlett készlete felhalmozódjon.

Ugyanakkor a Vetements divatiparban betöltött pozíciójának egyik legfóbb oka az, hogy a márka szorosan kapcsolódik a digitális média gyakorlataihoz és a kortárs digitális kultúra alapos megértéséhez. Gvasalia egyik interjújában így nyilatkozott (Petersen 2016): „Az iPhone-om mindig nálam van, keresgélek rajta, fent vagyok az Instagramon, a Facebookon vagy csak netezek úgy általában. Óriási mennyiségú információhoz férek így hozzá, melyet beszippantok, majd átvezetem a termékbe - akarjuk vagy nem akarjuk, az internet itt van." Egyik fontos fogalom, mely áthatja interdiszciplináris tervezôi gyakorlataikat (lásd Skjulstad 2017b), az internetes mém fogalma. Ahogyan a divat játékosan magáévá teszi a Jenkins által (2006) kezdetben konvergens kultúrának nevezett részvételi gyakorlatokat, ez a kultúra a dizájn-gyakorlatok középpontjába kerül - a termékek és ruhadarabok anyagának tervezésétól kezdve a promotálás és közvetítés gyakorlataiig. 


\section{Internetes mémek}

Az internetes mém fogalma Richard Dawkins evolúcióelméleti könyvéből, $A z$ önzö génbôl (1979) származik. Dawkins azt fejti ki, hogy az élet minden formája a génhez, a DNS-hez, a molekulához hasonló diszpozitívumok replikációjából származik, és ez a replikáció az alapja az evolúciós folyamatoknak. Dawkins amellett érvel, hogy a mémek a dallamok, a gondolatok, az öltözetek, a divat, az edények készítésének vagy a boltívek megépítésének a módozatai (1979: 178): „Éppúgy, ahogy a gének azáltal terjednek el a génkészletben, hogy spermiumok vagy peték révén testból testbe költöznek, a mémek úgy terjednek a mémkészletben, hogy agyból agyba költöznek olyan folyamat révén, melyet tág értelemben utánzásnak nevezhetu[hk. ${ }^{[2]}$

Miközben a genetikus változás egy alapvetôen lassú folyamat, a kulturális hordozók egyének közti cseréje nagyon gyors és nagyon sokféle. Az internetes mémek mediális jelensége az emberi társadalom és kultúra közvetítési és cseremechanizmusainak leírásába gyökerezik.

Az internetes mémeknek szentelt elemzésében Patrick Davidson médiaelemező (2012) az olyan kulturális hordozóként határozza meg azokat, melyek gyakran viccként jelennek meg és online hálózatokon keresztül terjednek. A mémek változékonyak, folyamatosan mozgásban vannak, mialatt többé vagy kevésbé állandó elemekből épülnek fel, és olyan, folyamatosan változó szabályokhoz és sztenderdekhez alkalmazkodnak, mint ahogyan például a 4-chan online fórumon olvashatók (Nissenbaum\&Shifman 2017).

Ha a Vetements közvetítési gyakorlatait az internetes mémmel kapcsoljuk össze, világossá válik, hogyan hozza mozgásba a tervezôi közösség a részvételi gyakorlatokat. Ezeket úgy tervezték meg, hogy mindenkit arra sarkalljanak, keltse életre a márka esztétikáját anélkül, hogy egyetlen ruhadarabot is meg kellene vásárolnia. Ezek a folyamatok egy olyan részvételi virális divatot hagynak érvényre jutni, melyet a mediációs folyamatok, a közösségimédia-technológiák és a közvetítési gyakorlatok határoznak meg. Limor Shifman (2014) az internetes mémeknek szentelt lapszámban a fotóalapú mémek kulturális logikáját elemzi. Az internetes mémet úgy határozza meg, mint „olyan digitális elemek csoportja, melyek a.) közös tartalmi, formai és/vagy álláspontbeli jellemzókkel bírnak; b.) úgy alkották meg ôket, hogy egymásról tudomásuk van; c.) az interneten sok felhasználó közvetíti, másolja és alakítja át ôket" (2014: 341). Shifman szerint a különféle mémmúfajok a kortárs internetes kultúra alaposabb megértésének a kulcsai.

Shifman internetes mém fogalma egy ponton különbözik a Dawkins által bevezetett fogalomtól: ô a mémeket nem egyedülálló, majd fejlódô és elterjedố kulturális entitásként határozza meg. Az egyetlen mémnek való kitettség helyett, például egy viccet hallunk egy buliban, ahogyan Dawkins képzelte el, ma könnyedén találjuk magunkat szembe a verziók százával a mémek milliárdjai között. Vagyis ennek az állításnak a következményeként nem elkülönülô mémek alkalmi 
példányaival állunk szemben, hanem azzal, amit Shifman szövegek és képek hatalmas csoportjának nevez (uo.). A képek e nagy gyưjteményét a múvészetteoretikus David Joselit (2013) After Art címú könyvében képpopulációnak nevezi.

\section{Képpopulációk és divat a posztmúvészetben}

David Joselit a kortárs múvészeti és építészeti gyakorlatok hálózati globalizációjáról írva (2013) azt tárgyalja, hogyan feltételezi a Google korának múvészete viszonyok és linkek heterogén együttállását. Mindezt posztmúvészeti megközelítésként mutatja be. Joselit, a múvészetek mediális és posztmediális feltételeitôl (ld. pl. Krauss 1999) elmozdulva, melyeket nem tart különösebben produktívnak a kortárs múvészet gyakorlatai egy nagy részének megértését illetôen, átirányítja a figyelmet arra, hogy „a képek mit csinálnak (kiem. az eredetiben) akkor, amikor heterogén hálózatok által közvetítôdnek" (2013: xiv). Joselit a múvészetet sajátos valutaként közelíti meg, és hangsúlyozza, hogy a képek hatalommal bírnak. Arra figyelve, hogy a képek hogyan mozognak, hiszen a közvetítés és a csere a használatban levô valutát fémjelezi, Joselit a múvészeti intézményeket a valuta menedzsereinek tekinti. Ebben a kontextusban vezeti be a képpopuláció fogalmát. A képpopulációk a mozgásban levô képek olyan kiterjedt gyújteményei, melyek nem tartoznak egy helyre. Ugyanakkor osztott létezésük miatt mozgó értékkel rendelkeznek. Amit ô a kép megosztott és mindenütt jelenlevô robbanásaként lát, az a múvészet eredeti jelentésével éles ellentétben áll, melynek értéke a helyhez kötött eredetihez kapcsolódik, ahogyan azt Walter Benjamin állította (1935).

Mialatt Benjamin azt fogalmazta meg, mi történik a múvészettel a mechanikus sokszorosíthatóság korában, amikor számtalan másolat semmisíti meg az egyedit, amit ô az eredeti és egyszeri múalkotás aurájaként írt le. Joselit képpopuláció fogalma (2013), az aurával rendelkező múalkotással szembe helyezkedve, a félig kaotikus, mindent átható képek tömegéhez kapcsolódó értékrôl beszél. Benjamin aurafogalmára alapozva vezeti be a buzz fogalmát, mely egy mozgásban levô képpopuláció keltette hatásra vagy érdeklődésre vonatkozik. A buzz összehangolt mozgás eredménye, mely ahhoz a mintázathoz hasonlatos, amikor sok kép oszlik meg számos kis mikroesemény között, melyeknek nincs ugyan újabb céljuk, hanem egy nagyobb egységes terv részei. Joselit szerint a buzz a populáris kultúra része: „A képek, az emberek és az események olyan nagyságrendben sokszorozódnak meg, amit nem lehet elöre tervezni vagy megjósolni. Egyszer csak itt van egy gyújtópont, mánia vagy trend, és a hírességek automatikusan generálnak híreket: e jelenségek képesek arra, hogy önmaguktól megsokszorozzák leképezôdésüket” (Joselit 2013: 19). Ezek a megsokszorozódó képek dinamikus formák, melyeket a közvetítés hoz létre. Joselit nekünk szegezi a retorikai kérdést: hogyan írjuk le azokat az instabil esztétikai tárgyakat, melyek a képpopulációkból jönnek létre és kristályosodnak ki? Azt javasolja, hogy történetileg vizsgáljuk meg, hogyan konceptualizálták az egyén és az ôt körülvevô hálózatok viszonyát.

E technikák egyike az, amit Joselit a talált tárgy térben való újrakeretezésének nevez: a magazinokból, könyvekból vagy internetrôl letöltött képek más formátumokba való beépítése, 
amit kisajátításnak hívunk. E megközelítés nem hoz létre semmi radikálisan újat, pusztán a kifejezések és tárgyak manipulációját teszi lehetôvé. A kapcsolódások korában a konnektivitás túltermelése a kép gazdaságtanának kulcsa. És ez a formátum maga: a hatalom és az érték a kapcsolódásban van, nem az egyedülálló képben vagy az egyedülálló tárgyban.

A terek közötti kapcsolatok és a terekhez, emberekhez és intézményekhez kapcsolódó képek túltermelése mint gondolkodásmód könnyen átvihetố a Vetements közvetítési gyakorlatainak középpontjában álló megosztási és disszeminációs feltételek közé. Joselit képpopulációkról alkotott elképzelése beépül a Vetements tervezői gyakorlatainak alapvetô múködésmódjába, kommunikációjába, terjesztésébe, illetve a márka esztétikai és gazdasági értékének is kulcseleme (lásd továbbá Skjulstad 2017b). Hogy egy konkrét példára utaljak, 2017 februárjában egy rejtjeles üzenet jelent meg a márka Instagram-fiókjában. Az üzenetet kézzel írták rá egy ruhatisztító számlájára: „Vetements Dry Cleaning 02709/17 Secret Location LA., United States” (Vetements Ruhatisztítás 02709/17 Titkos helyszín, Los Angeles, Egyesült Államok). A poszt 17 ezer lájkot kapott, és a figyelem középpontjába került. A késóbbiekben közölték, hogy az esemény egy mindenki számára és nemcsak a csapat és a divatipar szakmai szereplói számára nyitott pop-up üzlet megnyitására vonatkozott.

\section{Ellentmondásos inkluzivitás}

Ahhoz, hogy a Vetements által alkalmazott taktikát azonosítsam, a Dry Cleaning címú eseményt vizsgálom. A Los Angeles-i Beverly Hillsben található épület elôtt, melyben galéria és exkluzív üzlet múködik, várakozó emberek sora kígyózik. A sor messze túlnyúlik a helyszínen, és a bolton kívül egyfajta spontán városi buliba fordul át. A helyszín, a Maxfield Beverly Hills, egy exkluzív ruha, cipố és lakberendezési üzlet - múvészeti galériának álcázva, a rendezvény idejére ruhatisztítóvá alakul át: egy valódi New York-i ruhatisztító berendezését szállították ide az alkalomból. A múanyag zsákokban sorakozó ruhák között (csakúgy, mint a ruhatisztítóban) fóliával bevont Vetements öltözetek lógnak. Néhány kifejezetten erre az alkalomra tervezett ruha is megbújik a többi között, és csak meghatározott számú árut lehet itt vásárolni. 
Közel 1500 ember gyưlt össze és várakozott a sorban, hogy részt vehessen az eseményen, amely jó példája a Vetements kétértelmú külsô kommunikációjának, miközben Gvasaliát nehéz lenne azzal megvádolni, hogy kettôs mércét alkalmaz. Az alkalomból vele készített interjúban (Medina 2017) azt állította, hogy az esemény a demokratizálódásról szól, hiszen bárki számára nyitott, aki érdeklődik iránta. Emellett nagyon Instagram-kompatibilis is, hiszen a közösségi élmény és a bensôségesség érzésének megosztásáról is gondoskodnak. Az egyének azon akarata és képessége, hogy tudósítsanak arról, hol vannak, mit csinálnak, és kikkel vannak együtt, része az egyéni identitásuk színrevitelének (Duffy és Hund 2015; Proitz és Eliasen 2016). A Vetements és aMaxfield egy olyan eseményt alkottak, amely mozgásba hozza a képeket. Potenciális hozadék a hashtaggal ellátott képek áradata, mely a buzzt kiváltó képpopulációhoz adódik hozzá, s melynek lehetôségfeltételeit azért hozták létre, hogy a márkát a figyelem középpontjába helyezzék.

A Vetements éppen az ilyen populációk erejét képes generálni és hatékonyan mozgásba hozni. Azzal, hogy olyan eseményeket terveznek, mellyel nem csupán a divat szakértőit szólítják meg, akik oly gyakran vesznek részt divateseményeken, hogy szükségtelenek számukra az ilyen elôkészületek ahhoz, hogy önmagukat a divat elitjéhez társítsák, egy másfajta közönséget vonzanak. Így egy olyan pop-up esemény, mint amelyet a Maxfieldnél tartottak, a Los Angeles-i divatrajongók figyelmét akarja megragadni éppen akkor, amikor New Yorkban a divathét zajlik.

A Vetements azzal kelti a demokratikusság látszatát, hogy minden érdekelt fél számára megteremti a termékek megtekintésének vagy megvásárlásának lehetôségét, miközben mindezt speciális kiváltságként keretezi. Ez az alkalom Joselit szemüvegén keresztül vizsgálva élókép, egyfajta festôvászon, melyre emberek, események és helyszínek összekapcsolódásának számos lehetôsége kerülhet rá, mindamellett nagylelkú és invitáló házigazdák diszkrét márkázási gesztusa is. Mialatt olyan képi kapcsolódásokat és konfigurációkat segít elô, melyek a Vetements-t ehhez az egyébként szemiotikai kódokkal így is túlterhelt helyszínhez kötik, s melyeket olyanok figyelme közvetít, akik mind a Vetements-nal, mind a Maxfielddel kapcsolatba kerültek, a buzzt mint közös eredményt könyvelhetik el, a szó szoros értelmében egymás hátát vakargatva.

A figyelem, amelyet a Vetements ennek az eseménynek köszönhetôen generál, azt a kétértelmúséget is jól illusztrálja, mely e divatközösség önmegjelenítését áthatotta. Egyrészt azt állítják, korlátozzák az eladásra kerülô ruhadarabok, termékek darabszámát, hogy állandó keresletet teremtsenek, másrészt elkerülik a divatjamúlt, státuszszimbólumként már nem múködô darabok felhalmozódását.

Ahogyan a divat változik, a keresett darabokból a könnyen elérhetô ruhák hamar felesleges termékké válnak, a túl könnyen megszerezhetô darabokat már nem érzékeljük divatosnak. Meglehetôsen ambivalens, hogy a Maxfield showroom eseményén a túlfogyasztásra emlékeztetnek, miközben előre eltervezetten adnak el nekünk luxus ruhadarabokat. Az épületen kívül, egy Jean Prouvé által tervezett hatalmas üvegkocka csordultig van töltve régi bolhapiaci ruhákkal, mintegy memento mori kommentárként összekeverve néhány Vetements darabbal; ezzel is jelezvén, hogy ezek a divattárgyak akár maguk is félredobott textilhulladékká válhatnak a késôbbiekben. Mindez 
arra szolgál, hogy az ellentmondásosságból divatos mennyiséget tegyenek hozzáférhetôvé, az ócskapiaci felesleges ruhák hatalmas kupacban kiállított dózisa egyszerre invitál luxusvásárlásra, miközben magán viseli a túlfogyasztás jegyeit és a saját dizájnt is az egyre növekvô ruhakupacba sorolja.

A kétértelmúség színrevitelével egyidejúleg megkönnyítik a luxustermékek impulzív vásárlását (mivel ezek megvételére kizárólag az adott pillanat töredékében van lehetôség egyfajta privilégiumként), de közben a túlfogyasztás elkerülésére szólítanak fel, és mindezt környezettudatossági kérdésekkel is összekapcsolják. Így a Vetements érzékelhetôen a kritikai reflexió arénáját konstruálja meg, miközben önmaga is a probléma része. A Los Angeles Timesban megjelent interjúban (Medina 2017) Guram Gvasalia a következő kijelentést tette: „A piac meglehetôsen telített. Olyan sok termék van, hogy senkinek sincs igazán szüksége több ruhára.” A következô mondatában már azt hangsúlyozza, hogy a Vetements egészen bizonyos abban, hogy mindenkinek lehetôséget teremtenek a termékeikhez való hozzáférésre, mintha ez már önmagában is kiváltság lenne. Az eseményrôl a Los Angeles Timesban megjelent cikkében Medina (2017) a következőket írja:

Los Angelesben egyre növekszik a közösségi médiához értô hipszter divatrajongók száma. Az esemény egyfajta »mézesmadzag« volt, és kevéssé szólt a hagyományos vásárlásról, inkább egy újfajta, Instagram-kompatibilis tapasztalati lehetôségnek bizonyult. »Ha ruhát kell vásárolni, azt ma már egyetlen gombnyomással online megteheted. Ha a fizikai térben vásárolsz, akkor az élményhez már egy hozzáadott értéket keresel - az élményét...“

Azzal, hogy ideiglenes kapcsolat jön létre az esemény és a sajátos geográfiai tér, illetve a helyspecifikusan kialakított termék között, pozitív jelzést bocsátanak ki az elismerés csábította tehetôs Los Angeles-i fogyasztók felé, mialatt New York a divathetek okán egyébként is a reflektorfényben van. Azzal, hogy a Vetements egy ilyen helyspecifikus eseményt hoz létre vásárlói csoportjának, kiszolgálja a Beverly Hills-i divatszcénát egy olyan közösségi és mediatizáló keretet megteremtésével, amelyhez a közönség is kapcsolódhat.

\section{Az együttmúködés mint hálózati divat}

A mémek nemcsak a digitális mediáció promóciós stratégiái az Instagramhoz hasonló közösségi platformokon, hanem a materiális tárgyak és ruhák dizájnját is áthatják (Skjulstad 2017b). A Vetements a 2017-es tavaszi-nyári kollekcióhoz több együttmúködôvel is leszerzôdött, a luxuscipóket tervezô Manolo Blahniktól kezdve a Champion sportmárkán át, a Canada Goose tollkabátokig, és a Levi’sig, csak hogy néhányat említsünk. A hálózati tervezés és az együttmúködésen alapuló mediációs stratégia példája ez. Ugyanez figyelhetô meg a Levi’s farmer de- és rekonstrukciójának példáján keresztül, ahol a Vetements különbözô, a Levi’s eredeti dizájnjához tartozó farmerek darabjait illesztette össze, és így önálló „remix” dizájn született. A zsebek máshova kerültek, a varrást zipzárak váltották fel, és a szárhossz egyenlôtlen lett. Bárki, aki 
rendelkezik egy varrógéppel és egy régi farmerrel meg tudja varrni, ki tudja szabni és el tudja készíteni a saját verzióját. S bármely high-street márka is lemásolhatta volna, hiszen nehéz lenne eredetirôl beszélni anélkül, hogy a Levi’snek a farmer invenciójában és népszerúsítésében játszott szerepét elismernénk.

A Vetements lehetôvé teszi a ruhadarabok és egyéni stílusuk másolását, miközben a Levi’snek tulajdonított eredetibôl indul ki, másol, remixel, és másolja a másolatot, de kulcsfontosságú, hogy ô maga váljon másolatok tárgyává. Ahogy Nissenbaum és Shifman (2014) médiakutatók is hangsúlyozzák a 4chan oldal véletlenszerúen kiválasztott mémjeirôl írt tanulmányukban, a mémeket a fórumon különféle módokon fogadják be vagy zárják ki. Shifmanék fóként azt hangsúlyozzák, hogy a mémek kulcsszerepet játszanak ezen a weblapon az elfogadható és elfogadhatatlan örök vitájában, így a mémek úgy múködnek, mint e meghatározott szubkultúra tagjainak fontos megkülönböztetô jegyei, távolságot teremtve azokkal szemben, akiknek nincsen meg a megfeleló háttértudásuk ahhoz, hogy az online közösséghez tartozzanak.

Miközben Benjamin az eredetire koncentrált, az eredetiség gondolata a mémek múködésének kontextusában nem releváns. A kiválasztódás, reprodukálás, a terjedés és a mutálódás módja a lényeges. Mindez összefüggésben áll a Vetements különféle öltözékei és az eredeti közötti kapcsolattal (mint a sokat említett DHL póló, melyre a szöveg egy adott pontján visszatérek), illetve azzal, ahogyan a Vetements viszonyul más márkáknak a Vetements termékeket és darabokat érintô másolataihoz, így például a Vetememes-nak hívott paródiamárkához. Mindez a Vetements paródiákhoz való viszonyában válik nyilvánvalóvá. Az, ahogyan a kópiákat kezelik, fényt vet a digitális populáris internetes kultúra részeként értett divatmediáció és márkázás változó gyakorlataira.

\section{A kulturális hitelesség kiépítése}

Az elmúlt 15 év alatt az olasz luxusmárka, a Prada intenzíven együttmúködött az Office of Metropolitan Architecture-rel (OMA). A többek között Rem Koolhaas tervezőépítész és kutató által vezetett irodának már hosszú ideje a horizontján volt a Prada mint a kulturális márkázás fejlôdési lehetôségének egyik sarokköve avantgárd építészeti megrendeléseik miatt (Ryan 2007; Skjulstad 2014). Többféle okra hivatkozva, az építészettól kezdve a divatfilmek megrendezéséig (Skjulstad \& Morrison 2016), a Pradát a múvészet és a magaskultúra megvilágosodott védôszentjeként jelenítik meg (Ryan 2007). Az OMA hosszú távú törekvése, hogy a vásárlást kulturális törekvésként rajzolja újra, úttörố jellegú, s a vásárlás tereit is ennek alávetve rendezik át - múzeumokat és mítoszokat építve be az online és offline terekbe.

Azokat a kultúrákat, amelyekben a Prada pozicionálja magát, népszerúen „magaskultúrának” nevezzük. A Prada része és kezdeményezôje volt annak, ami a késóbbiekben a divat mediatizációjában trenddé vált, azzal, hogy megbízást adott egy avantgárd építészeti szentély megalkotására, egy élményalapú, múzeum kinézetú tér létrehozására, lehetséges érintkezési 
pontként a márka és közönsége között - mintegy ellenpontozva a kiskereskedelmi üzletet.

Emellett múvészeti alapítványt is múködtet, a Fondazione Prada komoly szereplôje a nemzetközi múvészeti szcénának - akárcsak a Louis Vuitton, amely szintén egy hatalmas kortárs múzeummal rendelkezik Párizs külvárosában a neves Frank Gehry építész által tervezett épületben.

A múvészet területére való egyértelmú belépés márkázási gyakorlata hozzájárul ezen brandek ethoszához, ahogyan arra Smith és Kubler (2013) is rámutat, vagyis kulturális hitelességet generál. A divat és múvészet közötti kapcsolat igen változatos lehetôségeket kínál, és sokkal inkább érinti a divattervezést magát, mintsem hogy egyszerú márkázási összetevố maradjon. Mialatt a múvészet és a divat ezen tartományok között oszcillál, vagy teljesen összekapcsolja ôket - egy kettôs ontológia részeként (Bik Bandlien 2016) ezen mezók egymás lefedésének is tekinthetôk -, a múvészet egyben divat lesz és fordítva. Mialatt a divat és a múvészet közötti együttmúködés formái virágzanak, a múvészet abban is jelentôs szerepet játszik, hogy a vezetô divatmárkák a kulturális tájképben hogyan pozicionálják önmagukat. Ezen a térképen, ahol a múvészet a divat kulturális pozíciójának legitimációjaként szolgál, a Vetements saját gyakorlataiban megfigyelhető antiintellektualizmus markáns kontrasztot teremt. Mindamellett, hogy a Vetements kiszolgálja a digitális bennszülöttek közönségét, élesen megkülönbözteti magát a fennálló establishmenttôl, mialatt olyan közismert múvészeti stratégiákat alkalmaz, mint a kisajátítás vagy a provokáció, beágyazódva a digitális kultúra és a közösségi média logikájába is.

\section{A másolat másolata}

Miután a márka bemutatta az olcsón kínált fekete esôkabátot, melynek hátán fehér betûkkel a Vetements felirat volt olvasható, nem tellett sok idôbe, hogy a Vetememes márkaparódia is színre lépjen. A paródiabolt és Instagram-profil eladásra kínálta a Vetements feliratot helyettesító Vetememes feliratú esốkabátot. A Vetememes weboldal felvezetố szövege a következô: „a paródia paródiája”. Érdekes módon a kalózmárka nem igazán fenyegeti a Vetements-t, mégis részese annak, és válasz arra az internetkultúrára, amely mindenekelőtt áthatja a Vetements-t, majd további jelentésrétegeket biztosít a számára, és tovább bonyolítja a Vetements-kirakóst is, s ez az, ami meghatározó jelentôségú.

Joselit (2013) alapján megállapíthatjuk, hogy a Vetememes hirdetései újabb réteget adnak hozzá a Vetements márka digitális térben betöltött pozíciójának szempontjából központi jelentôségú fotók és linkek teremtette buzzhoz. Ugyanakkor a divatmárkák gyakran váltak már paródia tárgyává vagy olyan kritikai megjegyzések áldozatává, melyek haszontalanságukra vagy a fogyasztói kultúra ellentmondásosságaira figyelmeztettek. Ami a Vetements-t a többi divatmárkától megkülönbözteti, az éppen az, hogy a másolás, a vita, a kétértelmúség beépül a tervezésbe, a divattervezés hozzáadott értékévé válik, s így a materiális és a mediatizált olyan mértékben kereszteződik, hogy a ruhadarab maga is mediatizációs eszközzé válik (Skjulstad 2017). Ahogy Lash és Lury (2007) is kiemelte, a média „dologiasítása” és a „dolog mediatizációja” figyelhetô meg annak eldöntésében is, hogy milyen ellentmondásos és vitát szító ruhadarab 
jelenhet meg a divatbemutatón. Ezek a viták a bizonytalanságra és a rejtélyre építô márkaidentitás bizonytalanságértékét növelik és a kirakóst izgalmasabbá teszik. Így a Vetements számos kortárs digitális médiakultúrához kapcsolódó mechanizmusból építkezik. A márka mém-gyakorlatairól Eror (2017) készített interjút:

Gvasalia tervei metatudatosságról tanúskodnak. Ironikus szándékuk meglehetôsen világos, és tudatos válaszra késztetik a közönséget, mely nagyrészt kizárólag az interneten találkozik munkájával. Demna tudja, hogy egy szinte azonos póló közvetlenül a DHL-tôl is megvásárolható az ár töredékéért. Valójában azt akarja, hogy vásárolj meg egyet, készíts róla fotót és taggeld be az Instagramon. Így az ô alkotása mémmé alakul, s egyaránt létezik a weben és a fizikai valóságában is.

Egy olyan mediális kontextusban, ahol az álhírek serkentik a vitát, a vita napirenden tartása a figyelem megszerzésének tudatos stratégiája. Elérni a megfelelô számú követôt és fenntartani azok állandó figyelmét, valamint a képpopuláció látható és sokoldalú jelenlétét, sokkal lényegesebb, mint erôteljesen kontrollálni és folyamatosan menedzselni a márka aprólékosan megtervezett, ragyogó bemutatását. Azon a divattérképen, ahol a globálisan sztenderdizált, tökéletesített és a digitálisan retusált, csillogó kép lejárt lemez, az, amit „autentikussá” alakítottak, válasz a darabjaira photoshoppolt, vizuális divatkultúrára. Az erre adott válasz részei a Vetements-turkálók és -boltok is, amelyek a szovjet éra iránti nosztalgia esztétikájával párosulva reprezentálják az annyira igényelt hitelességet, emellett friss színterei a divatfotók és helyszíneik problematikus viszonyában megnyilvánuló, gyarmati előítéletektól terhes divat egzotizálásának is. 

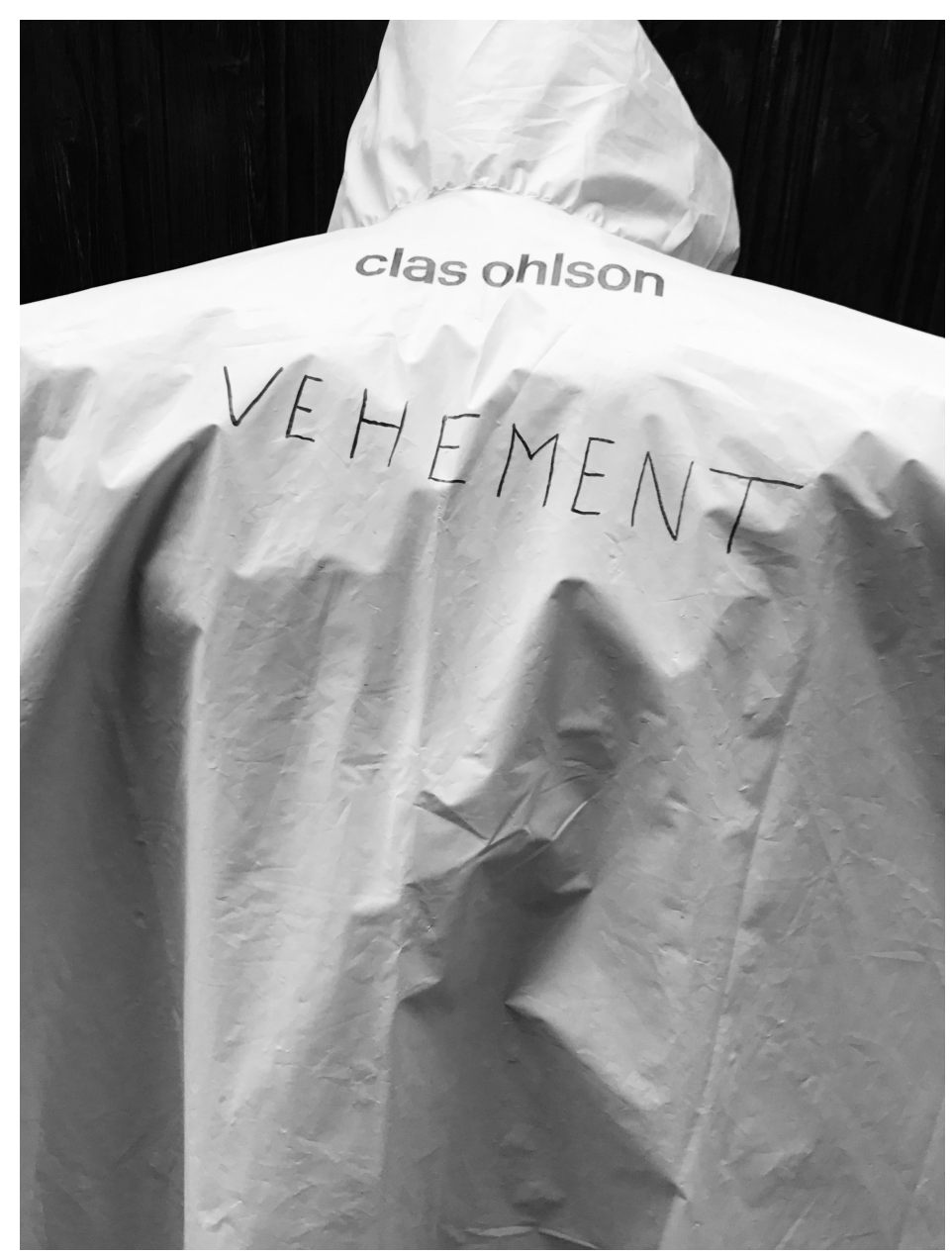

A másolat másolatának másolata. A képen egy Clas Ohlson vintage kézzel díszitett esóköpeny látható. Modell: Vemund Barstad

Bermingrud. Fotó: Synne Skjulstad.

S bár a mindennapi környezet elemei a Vetements mediatizációját nagymértékben befolyásolják, jól látható, hogy ezek a környezetek nem azok, amelyek a divatmédiában tipikusan előfordulnak, ahogyan azt a 2018-as ôszi-téli kollekció bemutatásakor a zürichi utcák és a városlakók esetében is megfigyelhettük. Mialatt a másolás aktusa más divatmárkákat megrémít, a másolatként létezés egyenesen beépül a Vetements mint indie-márka éthoszába, ami egy coolabb és divatosabb univerzumként múködik, megzavarva az uralkodó esztétikai stílusok fogalmát. Ebben a kontextusban a Vetements mémek modelljévé válik, olyan mintává, amelyet bárki kedve szerint használhat, mint a 4chan esetében, ahol a szabályok folyamatosan változnak. Ahogyan a Vetements kialakítja és változtatja a kereteket azonban, s így folyamatosan destabilizálja a tereket is, ô az, aki lefekteti a szabályokat. 


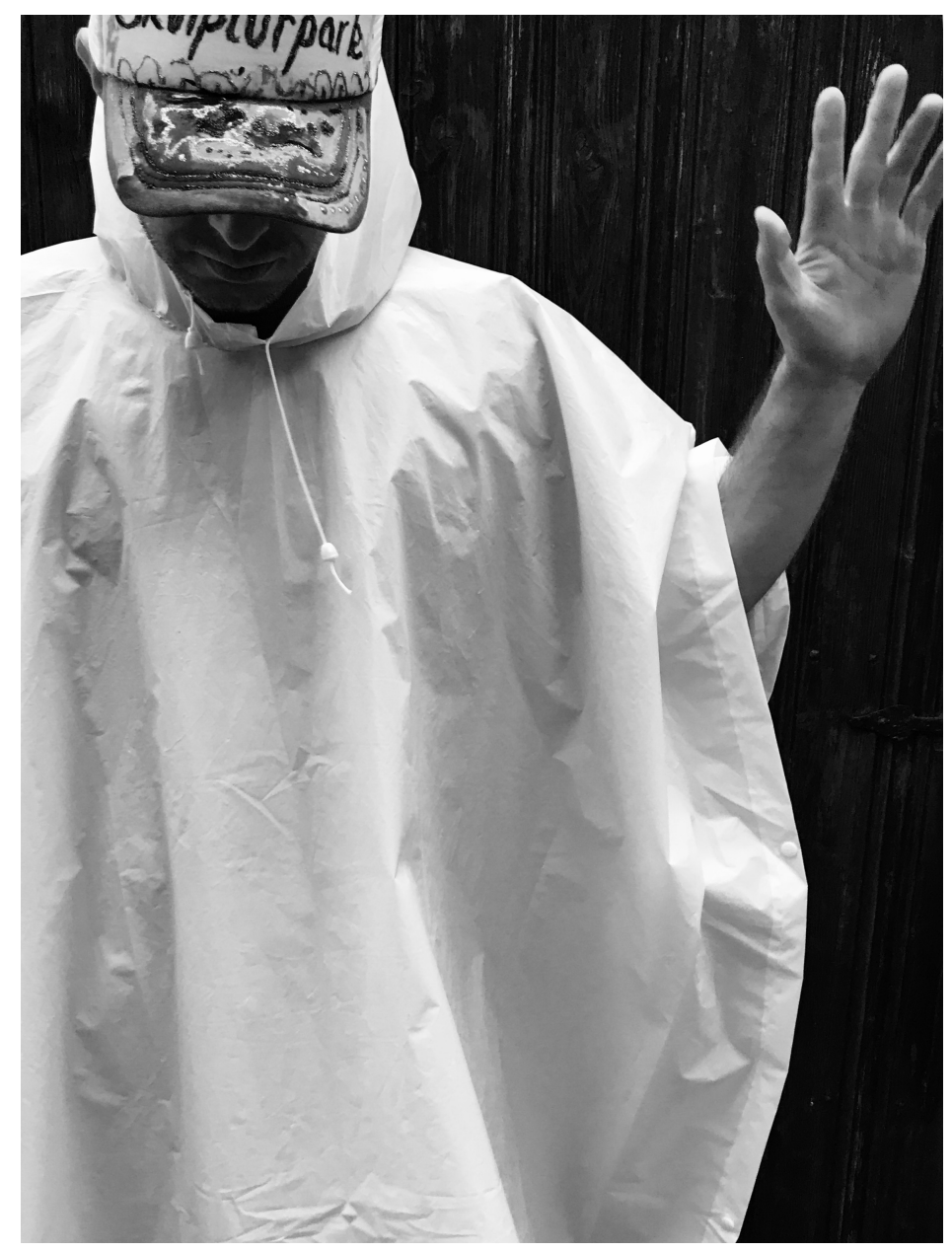

A másolat és egy másolatának másolata. A képen egy Clas Ohlson vintage kézzel diszitett esóköpeny és egy kézzel díszitett Panduro Hobby sapka látható. Modell: Vemund Barstad Bermingrud. Fotó: Synne Skjulstad.

\section{Rejtély, disszonancia és figyelem}

A múvészet területe alibiként szolgálhat a divat kulturális és esztétikai értékei számára. Nem neveznénk a Vetements-t kortárs múvészeti projektnek, világos azonban, hogy a márka a kortárs múvészeti szcéna trópusaiból és technikáiból nagy mennyiségben vesz kölcsön. Mialatt aktívan dezintellektualizálják a márkát, és ezzel egyidôben a múvészet világának gyakorlataira támaszkodnak, olyan disszonanciát teremtenek, mely kíváncsiságot és figyelmet válthat ki. A mûvészeti világban alkalmazott trópusok és technikák kisajátítása szembeszökô, bár nem felvállalt, sốt a márka időnként tagadja is. A gyakorlatban a felszín alatt zajló, ellentmondásos dizájnmegoldások láttán folyamatosan kapkodnunk kell a fejünket.

A digitális kortárs kultúra lüktetésének átvétele és a múvészet területéhez való kapcsolódás az elkülönülés egy olyan formáját hozza létre, mely lehetôvé teszi, hogy a Vetements mellett a többi divatház az eltûnt idôk megannyi konzervatív maradványának tûnjön. A kultúrát Raymond 
Williams (1958) médiakutató hétköznapi jelenségnek, életmódnak, a mindennapokba beágyazottnak tekintette. Williams tagadta azt az uralkodó elképzelést, melynek értelmében a kultúra a burzsoázia gyakorlataiba, irodalmi és oktatási intézményeibe ágyazott. Williams kultúrakoncepciója nyitott a mindennapi (röviden fogalmazva a mindennapi életben elóforduló) gyakorlatokra mint kultúrára.

Hasonló kultúrakoncepciót találhatunk a Vetements-nál még akkor is, ha az hozzá lett igazítva a populáris kultúra múködési mechanizmusaihoz, valamint a kortárs digitális média hálózatának múködéséhez és a digitális életformához, ahogyan azt Mark Deuze (2007, 2009, 2016) elmélete is alátámasztja. Ellentétben azzal a tervezói ethosszal, ahol a divatipar hagyományosan a fennkölt kulturális intézményekbe illeszkedik, a Vetements dizájnjai és azok közvetítése a mindennapokban találja meg a helyét. Nemcsak luxusdivatot, hanem olyan ruhákat is terveznek, amelyeket az emberek a mindennapokban viselnek, mint a farmer, a kapucnis pulóver, a tornanadrág és -cipó, ám gondoskodnak ezek luxusverziójáról is magasabb árfekvésben - ezekbe gyakran ready-made-eket építenek be, mint például a csizmasarokként vagy gyúrúként szolgáló öngyújtókat és fényszórókat.

A Vetements fotóin a divat a tömegkultúra és a digitális médiakultúra foglalataként jelenik meg, ahol az élet a digitális hálózaton keresztül bontakozik ki, létezése mediatizált és projektív, s ahol a divat olyan mémszerú öntôforma, melyben mások újrakeverhetik saját, utánozható gyakorlatuk egy változatát.

\section{Prospektív média és operatív dizájn}

Shifman (2014) mémekrôl szóló tanulmánya azt vizsgálja, hogy a mémek hogyan utalnak a jövôre, ellentétben azokkal a hagyományosabb fotográfia-megközelítésekkel, melyek szerint a fénykép mint retrospektív forma egyszerre utal arra, hogy mi történik, és mi az, ami már megtörtént, mint ahogyan azt Barthes (1980) elmélete jelezte. Shifman (2014) kimutatja, hogy a mémek elôremutatóak, új verziók sorozatát generálják, így a jövôre fókuszálnak. A képalapú mémek e kategóriáját prospektív képnek nevezi. Ezek olyan képek, melyek magukban foglalják a jövóbeli cselekvésre vonatkozó elvárásokat. Ennélfogva azt az elvárást hordozzák magukban, hogy a jövôben megváltoztatják és átalakítják ôket, így olyan élő objektumként értelmeződnek, mely új verziók kiindulópontja lesz.

A Vetements mémjellegú gyakorlatára jó példa a Reebok sportmárkával való együttmúködés. A kollaboráció egyik következménye a fehér, átalakított Instapump Fury sportcipő, amely úgy néz ki, mintha filctollal firkálták volna össze, ahogyan az iskolás gyerekek törött karján a gipszet szokták. Ezek a tornacipók „zártak” abban az értelemben, hogy nem invitálnak senkit a vásárlók közül arra, hogy folytassák a dekorációt. Azonban, ha egyfajta divatmém-generátorként tekintünk rájuk, akkor a prospektív divat egyik formájaként is kezelhetôk, lehetséges példaként arra, hogy ezt bárki megteheti egy pár régi tornacipóvel. A cipő a részvételre és bekapcsolódásra invitál a 
sportcipő divatként és antidivatként is olvasható átalakítása által, közvetett módon a Vetements-t mégis a meghatározás hatalmával ruházza fel. A sportcipố kifejezi a Vetements

antiintellektualizmusának paradox jellegét. Amikor ilyen cipóket terveznek, mint egy firka, melyet bárki képes létrehozni, és extrém drágán árusítják, ambivalens érzetet keltenek: a tárgyak egyrészt tréfaként olvashatók, a divat kritikájaként, másrészt úgy is, mint a mindent megosztó digitális generációba való meginvitálás, amelyre e tárgyak vonzerôt gyakorolnak, és melynek tagjait fejlôdésre késztetik. A cipốk a divatmémek példáivá válnak, mivel prospektív részvételi cselekvésre hívnak fel. Mindamellett a Vetements által megtervezett mém a minta, mely elöre kijelöli a befogadók lehetséges válaszainak feltételeit. Ezek a cipók inkább a beszélgetésre, mintsem a sétára lettek tervezve, a ravasz prospektív cselekvésre - másolatként, vitairatként és rejtélyként, illetve szinte korlátlan tartalomgyártói figyelem és vita generátoraként. Ezek a cipők mint divatmémek egy hasonló fogalomhoz vezetnek el minket, a divattrollkodáséhoz, amit a jövôben egy további munkában szeretnék megvizsgálni. Olyan divatra utalnak vissza, melynek szándéka a figyelemfelkeltés, az áttörố tervezésen keresztüli ellenmondások felkeltése, a tudatos provokáció.

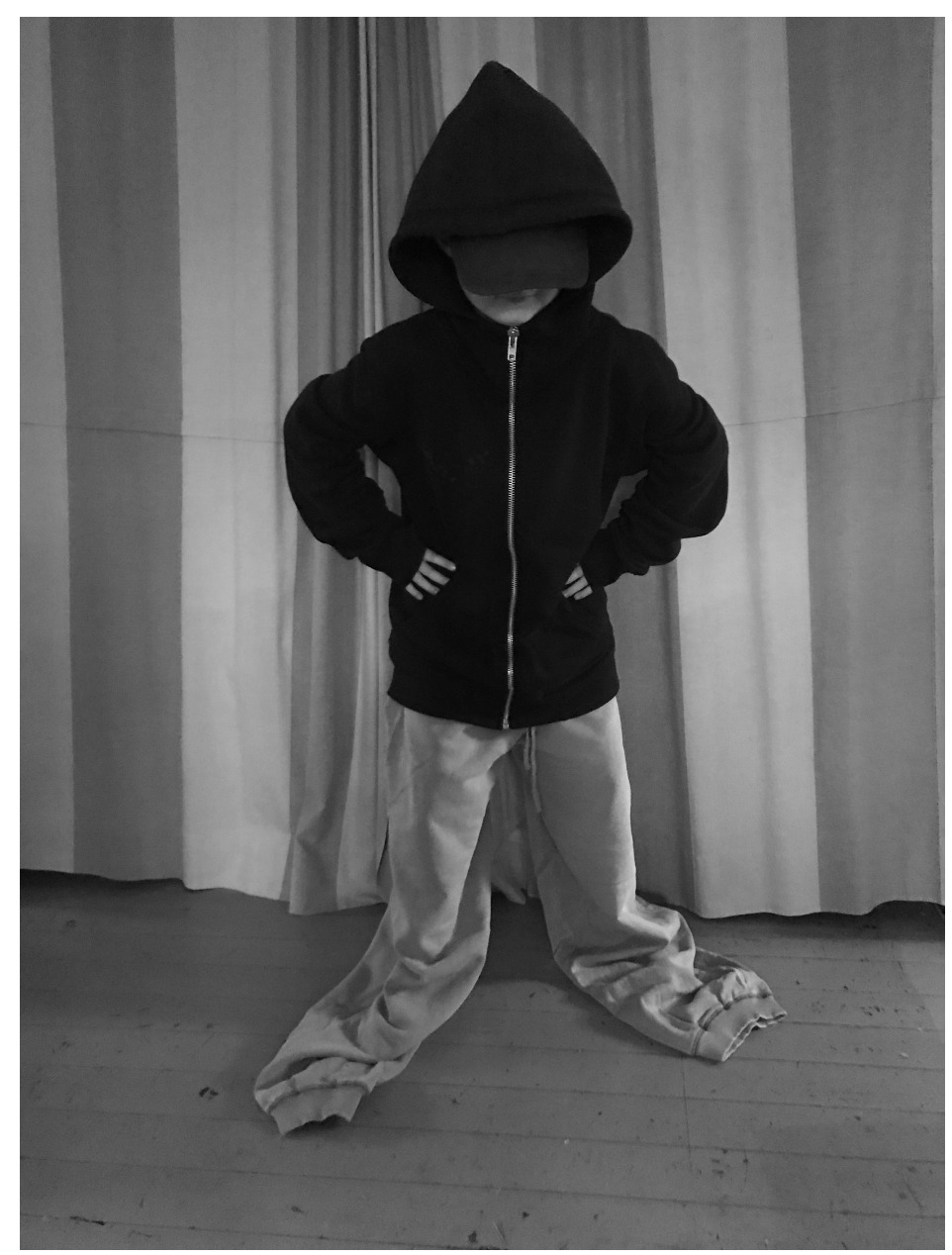

Túlméretezett pózolás vintage kapucnis felsöben és terepnadrágban.

Modell: Otto Skjulstad. Fotó: Synne Skjulstad.

Figyelmen kívül hagyva azt, hogy a cipók trollként behatolnak a tartalomgyártás területeire, a 
digitális kultúra és inherens kreatív idiotizmusának mélyebb megértését artikulálják

szofisztikáltan, egy olyan jelentés nélküli performatív kreativitást, melyet a digitális hálózatok társadalmilag és mediatizáltan is ünnepelnek (Goriunova 2012). Feszültség lép fel aközött, amit a Vetements mond, és amit felvet, s a fent említett cipők olvashatók felhívásként, a divat kritikájaként és drága, viselhetô tréfaként. Éppen ezen disszonanciát keltô ellentmondások vonnak titokzatos fátylat a márka köré. Valójában kirôl szól a vicc? Ez sem túl világos.

A Vetements amellett állt ki, hogy ók nem divatot terveznek, hanem ruhákat. Ugyanakkor az antidivat-mentalitás egy formáját közvetítik, mialatt párhuzamosan a múvészeti szcéna számos technikáját testesítik meg, mint például a ready-made-et, a cipôt, ahol a tárgyak és a felhasznált anyagok kontextusa és konfigurációja együtt hoznak létre egy új entitást és felszínt, és ahol mémszerú konfiguráción keresztül tudunk cselekedni. A leghírhedtebb példa erre az, amikor a 2016-os tavaszi-nyári kollekcióba a Vetements beépítette a DHL logisztikai társaságtól kölcsönzött sárga pólót, és limitált szériában forgalmazta több mint kétszáz dollárért.

\section{Együttmúködés/kisajátítás}

A 2017-es tavaszi-nyári kollekció a digitális megosztás kultúrájának egy másik sajátosságát is azonosítja, a ready-made kisajátítását a már létezô ruhadarabok, stílusok és olyan termékek újragondolásával ötvözve, amelyek hangsúlyozottan mindennapiak, és sokak gardróbjában megtalálhatóak szerte a világon, mint például az Eastpak márka egy teljesen közönséges hátizsákja. A hátizsák így a „vetementizáció” után teljesen úgy néz ki, mint az eredeti, ám finoman átdolgozták. Az arányokat megváltoztatták, és ráadásul az eredeti Eastpak logó mellett a zsákot a Vetements saját címkéjével is jelölték.

A teljes kollekció magán viseli a más múhelyekkel és márkákkal való kollaboráció jegyeit. Az a kétértelmûség, amely a Vetements-termékek többségét jellemzi, ezekben az együttmúködésekben is megtalálható. Azáltal, hogy mindezt egyidejúleg egy kreatív dizájnstratégia részeként, közönséges márkák, ruhadarabok és termékek divatos remixeléseként helyezi el, a Vetements kereskedelmi stratégiaként alkalmazza az együttmúködést és a kisajátítást, illetve fogalmilag brandmechanizmusként kérdez rá erre a megközelítésre. Mindazonáltal azt állítják magukról, hogy nem konceptuálisan múködnek. Ezek az ellentmondások vitát generálnak. Ily módon a Vetements úgy tûnhet fel, mintha valamiféle kritikai és konceptuális munkát végezne a divatban és digitális korunk mediatizált világában, mialatt tagadja saját megközelítésének intellektualizálódását. Például Gvasalia azt állítja a Miles Socha által (2015) készített interjúban: „Mi nem próbáljuk meg áthágni a divat határait, csak olyan ruhákat készítünk, amelyeket az emberek viselni szeretnének." 


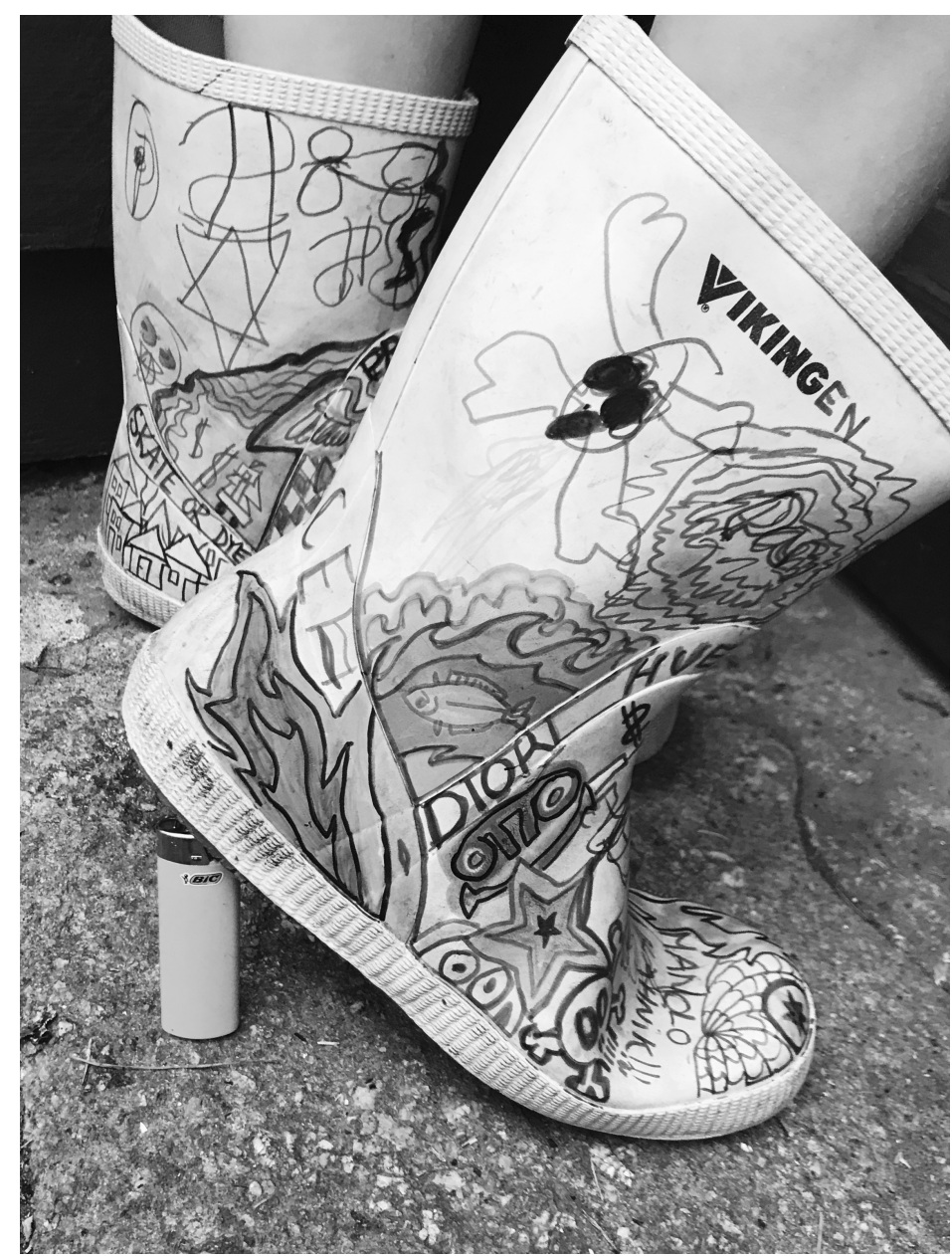

Ezt a Viking gumicsizmát a szerzó édesanyja több mint húsz évvel ezelôtt „Manolo Blahniknak” nevezte. A Reebok/Vetements

Instapump Fury együttmúködésre válaszul újradizájnolva. A Bic gyújtó-sarok hivatkozás is e gesztusnak része. Modell: Otto Skjulstad.

Fotó: Synne Skjulstad.

Azt állítva, hogy olyan ruhákat gyártanak, amelyeket az emberek hordani szeretnének, és amelyek már eleve részei a kortárs alapruhatárnak, miközben ezeket a vágy tárgyává transzformálják, konceptuálisan és a gyakorlatban is feltárhatják a divat mögötti kulcsmechanizmusokat, miközben azt hangoztatják, hogy ốk csak ruhákat terveznek. Amikor azt állítják, hogy nem akarják a divat illúzióját vagy vágyálmát létrehozni, mindössze ahhoz ragaszkodnak, amit az emberek akarnak, a Vetements egy olyan térben pozicionálja magát, ahol az eszképizmus és a hagyományos divatmediációk illúziói szemben állnak a mindennapi digitális divatkultúrákkal - ahol bárki színre viheti magát, amelyekben bárki részt vehet, és ahol bárki középpontba kerülhet. Az Alexander Furynak adott interjúban (2015) Demna Gvasalia kijelenti, hogy nem álmot kell kreálni, hanem azt kell tervezni, amit az emberek akarnak: „Az »Óh a divat vágyálmát akarjuk megteremteni«-típusú illúziók nem léteznek. Mi csak olyan ruhákat akarunk készíteni, amilyeneket az emberek akarnak.” Így a kulturális kontextus hétköznapi kép digitális áramlataként, nem pedig a kifinomult polgári intézmények, valamint a fényúzó eszképizmus múvészi álmai felôl határozható meg. 


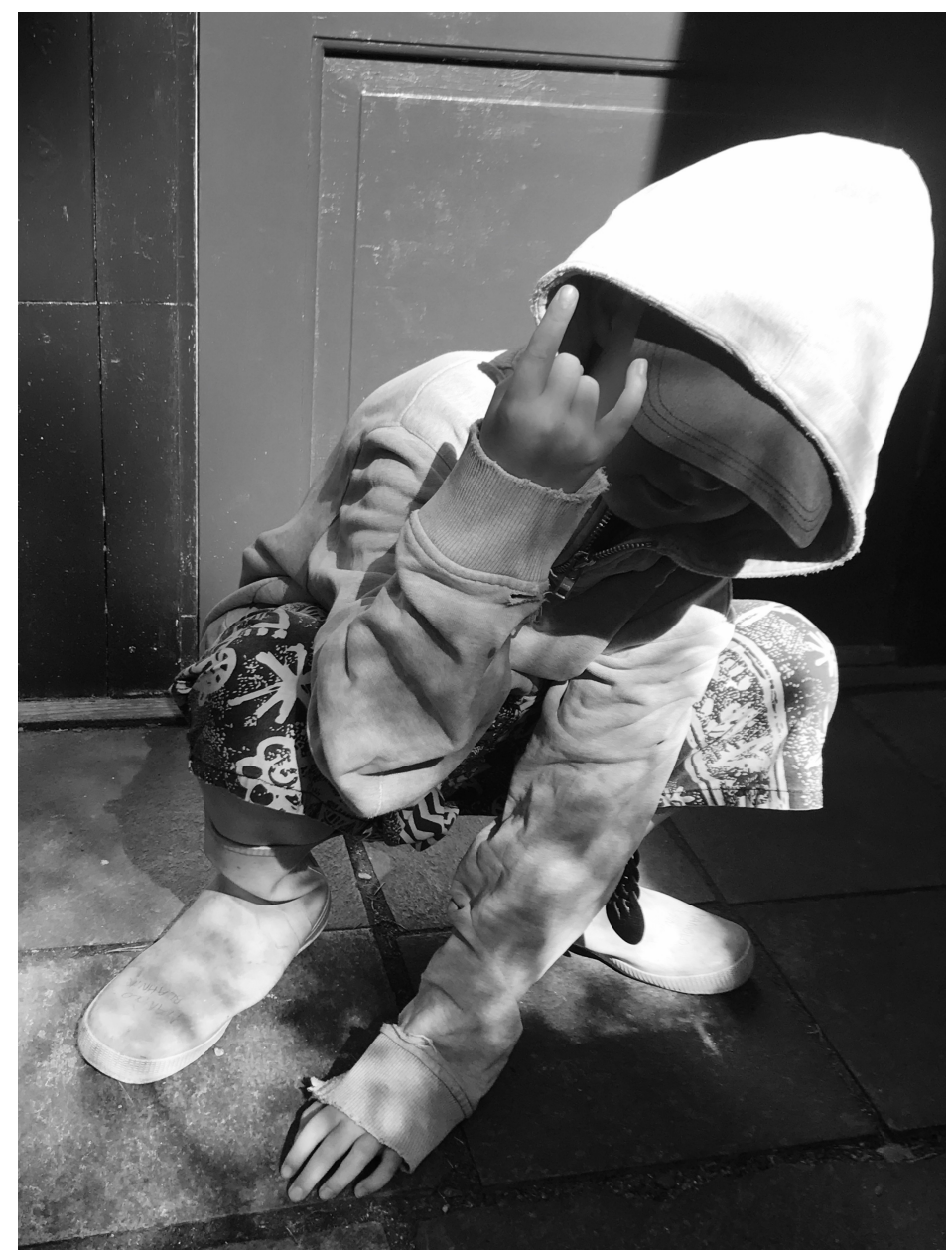

Kapucni, sapka és attitüd válaszul a Vetements rebellis és megosztó önpozicionálására. Modell: Otto Skjulstad. Fotó: Synne Skjulstad.

\section{A demokratizálódás önfarkába harap}

A számtalan hirdetésben és divatfotón megismételt idealizált reprezentációval szembemenve a Vetements önmagára irányítja közönsége figyelmét, lehetőséget adva a fiataloknak arra, hogy okostelefonjaik segítségével, mint a mémek, mediatizáltan jelenhessenek meg egy szubkulturális térképén - például, miközben egy metálbanda logójával ellátott hosszú ujjú kapucnis felsốt viselnek a Vetements-ra tett utalásként, akkor a márkáéhoz hasonló esztétikai térben helyezik el magukat. A mediációs mimikri aktusainak jövóbeli lehetôségét hordozó divatmémek tervezésén és terjesztésén keresztül egy olyan sémát hoznak létre, amely egyéni kézjegyükkel van ellátva, ugyanakkor a séma módosítható, másolható és egyfajta esztétikai vászonként jelenik meg, amelyre lehetséges mediációk és divatgyakorlatok vetíthetók rá. Aktuális közösségi technológiai platformjaink és mediatizált divatkultúráink a materiális dizájn, annak közvetítése és közönsége között mediációs hurkot teremtenek. A highsnobiety.com online platform meghívására Aleks Eror beszélgetett Guram Gvasalia CEO-val, a Vetements kreatív igazgatójának testvérével, aki a 
Vetements-t a digitális világhoz kapcsolta (2015): „Demna jól tudja, hogy majdnem ugyanazt a pólót vásárolhatod meg közvetlenül a DHL-tôl az összeg töredékéért. Valójában azt akarja, hogy vegyél egyet, lój egy fényképet, és taggeld be ôt az Instagramon. Ez a weben és a fizikai valóságban egyszerre létezô jelenség alakítja munkáját mémmé.” Azáltal, hogy közönségük kulturális önmeghatározásának már részét képező ötletekhez, irányzatokhoz és létezô ruhadarabokhoz, termékekhez nyúlnak, online életekbe hatolnak be, dialógust kezdeményeznek, miközben begyüjtik közönségük online esztétikai tevékenységének termését.

\section{Konklúziók és következmények}

Napjainkban a divatmédia egyik legújszerúbb vonása a részvétel és a megosztás kortárs kultúráival való lépéstartás. Mindez az internetes mémek hatását feltételezi, amelyek modellt biztosítanak a divatipar, a közönség és a vásárlók részvételéhez. A Vetements elemzett esete azt érzékelteti, hogyan érhetô el mindez úgy, hogy a divattervezési folyamatban mind a médium, mind a kreativitás és a tervezés is hangsúlyossá váljék (Skjulstad 2017). A Vetements szándékosan épít az ellentmondásra és a provokációra mint a kereslet generálásának és a figyelem felkeltésének eszközeire annak érdekében, hogy elhelyezze a márkát a közbeszédben. A kisajátító tervezés, a hivatkozás, sốt a mimikri gyakorlatát is zászlajára túzi, hogy ironikusan és kreatívan érvényesítse saját produktivitását és piaci identitását.

A Vetements tevékenységének mélyreható elemzése megmutatta, hogy e dinamikák folyamatosan megkérdôjeleződnek, és a gyakorlatban a megvalósíthatónak és a nem-megvalósíthatónak a keretezésében a divatipar mediatizált hatalmi formái nyilvánulnak meg. Egy átfogóbb kitekintésben amellett érveltem, hogy a médiakutatásból származó koncepciók és belátások fontos információkkal szolgálhatnak a kortárs divat gyakorlatának, a mémeknek és a részvételnek a megértéséhez. A „divatmémek” fogalmát részben ennek igazolására hoztam létre.

Ami várható (elképzelt képek formájában bekövetkezô események, a „pozicionálás” és a projekciók), jövôbeli megismétlésre kínálja fel magát. Eszerint a jövô felé mutató álláspont szerint a továbbiakban identifikációs utakat kell keresni, és ki kell jelölni az újratervezés és a tervezett változások tereit, melyeket valószínúsíthetôen a divat és a média összefonódásán keresztül lehet majd elérni.

Fordította Egri Petra és Keszeg Anna

A fordítást ellenôrizte Füzi Izabella

[A fordítás alapjául szolgáló mú: Synne Skjulstad: Vetements, Memes, and Connectivity: Fashion Media in the Era of Instagram. Fashion Theory, 24.2. 181-209. DOI: 10.1080/1362704X.2018.1491191] 
1. A post-art fogalmát posztmúvészetként fordítottuk. A fogalmat a tanulmányban hivatkozott Joselin-kötetre is utalva használja a szerzô (2013). A „múvészet utáni” és a „posztmúvészet” kifejezések eltérô koncepciót képviselnek, ezért maradtunk itt a „posztmúvészet” kifejezés mellett, hogy a múvészet utáni kifejezéstôl elkülöníthető legyen. [A fordítók megjegyzése.]

2. Az idézetet a magyar fordítás alapján közöljük, az oldalszám is a magyar fordításra utal. [-A forditók.]

\section{Irodalomjegyzék}

- Andersen, Charlotte (2006): Modefotografi: En Genres Anatomi. Copenhagen, Museum Tusculanums Forlag.

- Arnold, Rebecca (2009): Fashion: A Very Short Introduction. New York, Oxford University Press. https://doi.org/10.1093/actrade/9780199547906.001.0001

- Arvidsson, Arvid (2006): Brands. London, Routledge. https://doi.org/10.4324/9780203640067

- Barthes, Roland (2010): Camera Lucida: Reflections on Photography. Ford. Richard Howard. New York, Hill and Wang.

- Benjamin, Walter (1968): The Work of Art in the Age of Mechanical Reproduction [1935]. In Illuminations. Szerk. Arendt, Hanna. New York, Schocken Books. 217-253. https://doi.org/10.4324/9780429498909-39

- Bik Bandlien, Charlotte (2016): Mot en Antroplogisk Praksis: HAiKing som Forskning og (Post)Kunstnerisk Praksis [Towards Anthropological Practice: HAIKing as Research and (Post)-Art Practice]. Kunst og Kultur, 4. 99. 218-227. DOI: 10.18261/issn.1504-3029-2016-04-04. https://doi.org/10.18261/issn.1504-3029-2016-04-04

- Bolter, Jay David and Grusin, Richard (1999): Remediation: Understanding New Media. Cambridge, Massachusetts, The MIT Press.

- Cubitt, Sean (2013): Anecdotal evidence. NECSUS: European Journal of Media Studies, 2013. május 2. URL: http://www.necsus- ejms.org/anecdotal-evidence/. https://doi.org/10.5117/NECSUS2013.1.CUBI

- Davidson, Patrick (2012): The Language of Internet Memes. In The Social Media Reader. Szerk. Mandiberg, Michael. New York, New York University Press. 120-137.

- Dawkins, Richard (1979): The Selfish Gene. New York, Oxford University Press. Magyarul: Dawkins, Richard (1999): Az önzố gén. Ford. Síklaki István. Budapest, Kossuth Kiadó

- de Perthuis, Karen (2015): People in Fashionable Clothes: Street Style Blogs and the Ontology of the Fashion Photograph. Fashion Theory, 20. 5. 523-543. https://doi.org/10.1080/1362704X.2015.1115656

- Deuze, Mark (2007): Convergence Culture in the Creative Industries. International Journal of Cultural Studies, 10. 2. 243-263. https://doi.org/10.1177/1367877907076793

- Deuze, Mark (2016): Living in Media and the Future of Advertising. Journal of Advertising, 45. 3. 326-333. https://doi.org/10.1080/00913367.2016.1185983 
- Deuze, Mark (2011): Media Life. Media, Culture \& Society, 33. 11. 137-148. https://doi.org/10.1177/0163443710386518

- Duffy, Erin, and Hund, Emily (2015): „Having it All” on Social Media: Entrepreneurial Femininity and Self-Branding Among Fashion Bloggers. Social Media + Society. 1-11. https://doi.org/10.1177/2056305115604337

- Entwistle, Joanne (2009): The Aesthetic Economy of Fashion: Markets and Value in Clothing and Modelling. London, Bloomsbury. https://doi.org/10.2752/9780857854148

- Eror, Aleks (2015): Why Demna Gvasalia is the First Designer to Truly Understand Internet Culture. highsnobiety.com. 2017. 07. 31. URL: https://www.highsnobiety.com/2017/07/31/demnagvasalia-vetements-irony/.

- Fury, Alexander (2015): The Label Vetements is the most Radical Thing to come out of Paris in over a Decade. So What's the Big Idea? The Independent, 2015. 10. 16. URL: https://www.independent.co.uk/life-style/fashion/features/the-label-vetements-is-themostradical-thing-to-come-out-of-paris-in-over-a-decade-so-whats-the-big-a6692211.html.

- Goriunova, Olga (2012): New Media Idiocy. Convergence: The International Journal into New Media Technologies, 19. 2. 223-235. https://doi.org/10.1177/1354856512457765

- Jenkins, Henry (2006): Convergence Culture. New York, New York University Press.

- Jenss, Heike (2016): Introduction: Locating Fashion/Studies: Research Methods, Sites and Practices. In Fashion Studies: Research Methods, Sites and Practices. Szerk. Heike Jenss. London, Bloomsbury. https://doi.org/10.5040/9781474220163.0007

- Joselit, David (2013): After Art. New Jersey, Princeton University Press. https://doi.org/10.1515/9781400845149

- Karlsen, Faltin (2017): Onlineetnografi. In Metodebok for Kreative Fag. Szerk. Hans Erik Næss és Lene Pettersen. Oslo, Universitetsforlaget. 100-109.

- Khan, Nathalie (2012a): Cutting the Fashion Body: Why the Fashion Image is no longer Still. Fashion Theory, 16. 2. 235-250. https://doi.org/10.2752/175174112X13274987924177

- Khan, Nathalie (2012b): Stealing the Moment: The Non-Narrative Fashion films of Ruth Hogben and Gareth Pugh. Film, Fashion \& Consumption, 1. 3. 251-262. https://doi.org/10.1386/ffc.1.3.251_1

- Krauss, Rosalind (1999): A Voyage on the North Sea: Art in the Age of the Post-Medium Condition. London, Thames \& Hudson.

- Landow, George. P. (1997): Hypertext 2.0: The Convergence of Contemporary Critical Theory and Technology. Baltimore, The Johns Hopkins University Press.

- Lash, Scott - Lury, Celia (2007): Global Culture Industry. Cambridge, Polity Press.

- Lundby, Knut (2009): Introduction: „Mediatization” as Key. In Mediatization: Concept, Changes, Consequence. Szerk. Knut Lundby. New York, Peter Lang. 1-18.

- Medina, Marcy (2017): Vetements to unveil limited L.A.-inspired pieces at Maxfield pop-up event. Los Angeles Times, 2017. 02. 09. URL: http://www.latimes.com/fashion/la-igwwdvetements-event-maxfield-20170209-htmlstory.html.

- Milner, Ryan M. (2013): Hacking the Social: Internet Memes, Identity Antagonism, and the 
Logic of Lulz. The Fibreculture Journal, 22. URL: http://twentytwo.fibreculturejournal.org/fcj156-hacking-the-social-internet-memes-identityantagonism-and-the-logic-of-lulz/.

- Muriale, Sabina (2014): From Physical to Virtual: The Global Scope of Online Fashion Presentations. In Aesthetic Politics of Fashion. Szerk. Elke Gaugele. Berlin, Sternberg Press. 131-145.

- Nissenbaum, Asaf. \& Shifman, Limor (2017): Internet Memes as Contested Cultural Capital: The Case of 4chan's /b/ board. New MediaESociety, 19. 4. 483-501. https://doi.org/10.1177/1461444815609313

- Oakley Smith, Mitchell \& Kubler, Alison (2013): Art/Fashion in the 21st Century. London, Thames \& Hudson.

- Prøitz, Lin \& Eliasen, Kristoffer (2016): Self Image: From Self-Portrait- to \#Selfie. Oslo, Universitetsforlaget.

- Petersen, Lars (2016): What Fashion's Most Controversial Designer has to say about the Sweatshirt Trend. Refienery29.com. 30. 08. 206. URL: https://www.refinery29.com/demnagvasalia.

- Rocamora, Agnès (2016): Mediatization and Digital Media in the Field of Fashion. Fashion Studies, 21. 5. 505-522. https://doi.org/10.1080/1362704X.2016.1173349

- Rocamora, Agnès (2013): How New are New Media? The case of Fashion Blogs. In Fashion Media: Past and Present. Szerk. Djurda Bartlett, Shaun Cole és Agnès Rocamora. New York, Bloomsbury. 155-164.

- Ryan, Nicky (2007): Prada and the Art of Patronage. Fashion Theory, 11. 1. 7-24. https://doi.org/10.2752/136270407779934588

- Shifman, Limor (2014): The Cultural Logic of Photo-Based Meme Genres. Journal of Visual Culture, 13. 3. 340-358. https://doi.org/10.1177/1470412914546577

- Skjulstad, Synne (2017a): Mashing up the Fashion Image: Instagram Art, Fashion, and Technoculture in Douglas Abraham's Artistic Practice. Ekfrase, 1.2. 82-96. https://doi.org/10.18261/issn.1891-5760-2016-01-02-12

- Skjulstad, Synne (2017b): Who wore it Best? Understanding Mediated Fashion as Design. In NORDES 2017 Design + Power. URL: http://www.nordes.org/nordes2017/programme/index.html.

- Skjulstad, Synne (2014): Exhibiting Fashion: Museums as Myth in Contemporary Branding and Media Culture. Elöadás a következô konferencián: NODEM: Engaging Spaces, Design and Digital Strategies, Varsó, November 1-3. URL:

https://www.researchgate.net/publication/269398051_Exhibiting_Fashion_Museums_as_myth_in_contempor

- Skjulstad, Synne \& Morrison, Andrew (2016): Fashion Film and Genre Ecology. Journal of Media Innovations, 3. 2. 20-41.

https://doi.org/10.5617/jmi.v3i2.2522

- Socha, Miles (2015): Demna Gvasalia: His Own Rules. WWD, 2015. 11. 18. URL: http://wwd.com/fashion-news/fashion-features/demna-gvasalia-balenciage-vetements10279574/

- Uhlirova, Marketa (2013): The Fashion Film Effect. In Fashion Media: Past and Present. Szerk. Djurdja Bartlett, Shaun Cole and Agnès Rocamora. London, Bloomsbury. 118-133. 
https://doi.org/10.5040/9781350051201.ch-010

- van Dijck, José (2010): Flickr and the Culture of Connectivity: Sharing Views, Experiences, Memories. Memory Studies, 4. 4. 401-415.

https://doi.org/10.1177/1750698010385215

- van Dijck, José, and Poell, Thomas (2013): Understanding Social Media Logic. Media and Communication, 1. 1. 2-14.

https://doi.org/10.17645/mac.vlil.70

- Mitchell, W.J.T. - Hansen, Mark. B.N. (2009): Introduction. In Critical Terms for Media Studies. Szerk. W.J.T. Mitchell és Mark B.N. Hansen, vii-xxii. https://doi.org/10.7208/chicago/9780226532660.001.0001

- Williams, Raymond (1989): Culture is Ordinary [1958]. In Resources of Hope: Democracy, Socialism . Szerk. Robin Gable. London, Verso. 4-6. 
(C) Apertúra, 2020. nyár | www.apertura.hu

webcím: https://www.apertura.hu/2020/nyar/skjulstad-vetements-memek-es-konnektivitas-

divatmedia-az-instagram-koraban/

https://doi.org/10.31176/apertura.2019.15.4.1

(Q)opertúro 